\section{High-dosage Fluphenazine}

SIR,-Comment in your correspondence column has drawn attention to side-effects of phenothiazines, ${ }^{1-s}$ and there is current interest in the use of fluphenazine enanthate. I wish to draw attention to the value of highdose oral fluphenazine administration in acute schizophrenic illness. This therapeutic approach to a broad cross-section of psychotic patients has been studied by some French psychiatrists ${ }^{5}$ but has not been recorded in publications in English. The French authors comment on the remarkable tolerance of doses up to and even exceeding $500 \mathrm{mg}$. daily. They observed that side-effects of medication were definitely fewer in high doses as compared with those in doses of less than $50 \mathrm{mg}$. daily. In their opinion the clinical response to high doses was excellent. When evaluating dosage of fluphenazine one should bear in mind that it is 10 to 20 times as potent as chlorpromazine.?

Because of these favourable reports I have recently treated newly admitted patients who are in my opinion suffering from an acute schizophrenic illness by administering an initial dose of oral fluphenazine $100 \mathrm{mg}$. daily, and this is increased to $200 \mathrm{mg}$. daily within 48 hours and in one case to $400 \mathrm{mg}$. daily, the dose level being increased until there is evidence of response by psychiatric interview and observation of ward behaviour. Routine anti-Parkinsonian drugs have been given, either benzhexol $5 \mathrm{mg}$. three times daily, procyclidine hydrochloride $5 \mathrm{mg}$. three times daily, or benztropine methanesulphonate 2 to $4 \mathrm{mg}$. daily. I have observed 25 patients given doses of fluphenazine $100 \mathrm{mg}$. or in excess of this daily. There have been 12 females and 6 males given $100 \mathrm{mg}$., 4 females and 2 males given $200 \mathrm{mg}$., and 1 female given $400 \mathrm{mg}$. The only side-effects noted as possibly being due to the fluphenazine were excessive salivation in one female on $200 \mathrm{mg}$. daily, drowsiness and motor retardation in one female on $100 \mathrm{mg}$. daily, and slight jaw stiffness in one female on 100 $\mathrm{mg}$. daily. The absence of any serious sideeffects has been most impressive, and the lack of any persistent sensations of discomfor from the patients. In my observations of the therapeutic response I have been impressed by the anti-psychotic, socializing, and energizing properties of the drug and by the rapidity of improvement as compared with other phenothiazines.

I would like to note one illustrative example: a female aged 40 years with previous psychiatric inpatient admissions was brought to hospital by the police under the provisions of section 136 of the Mental Health Act. On examination she was thought-disordered, showed incongruity of affect, was deluded, excited, and aggressive. Fluphenazine was given, increasing to $400 \mathrm{mg}$. by the fourth day, and she was by then much improved and was discharged after three weeks. This response was more rapid and complete as compared with that recorded on previous admissions.

In conclusion fluphenazine appears to have this unusual property of being well tolerated in very large doses, provided antiParkinsonian agents are given, and the therapeutic response is such that further critical evaluation is indicated in planned controlled trials. - I am, etc.,

$$
\begin{aligned}
& \text { Banstead Hospital, } \\
& \text { Sutton, }
\end{aligned}
$$

REFERENCES

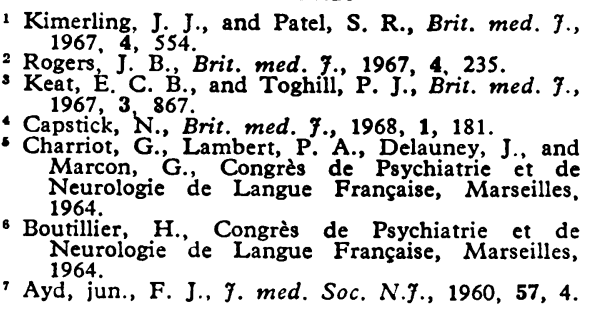

\section{Basilar Syndrome}

SIR,-If Dr. A. J. Macleod (23 March, p. 767) cares to glance at p. 174 of the fourth edition of my Textbook of Orthopaedic Medicine, volume I, he will find a discussion on the dangers of cervical manipulation. My calculation is that death is brought about in not more than 1 in 10 million manipulation of the neck. On the following page, under the heading of "Danger of Not Manipula ting," the disadvantage is emphasized of leaving a central disc protrusion where it is, to draw out the very osteophytes that eventually compress the spinal cord.

Provided manipulation is carried out using the techniques of orthopaedic medicine, and is confined to patients selected on the criteria set out in volume I, no untoward results are to be expected, and neither I nor any of the thousand physiotherapists I have trained in my time have (so far) caused lasting damage, let alone death.-I am, etc.,

London $\mathbb{W} .1$

James Cyriax.

Cyriax, J., Textbook of Orthopaedic Medicine,
1962, Vol. I, p. 174, 4th ed., London.

\section{Screening Tests for Phenylketonuria}

SIR,-I would like to comment on your leading article "Screening Tests for Phenylketonuria" (16 March, p. 656) and on the report in the same issue from Dr. James Farquhar and others in Scotland (16 March, p. 674).

The latter report has set out in clear terms the advantages offered by the Guthrie bacterial inhibition test over other screening procedures. Perhaps the most important poin made by this report is the simplicity of the administrative system and its fluidity which would enable it to be applied to other tests which may in time supersede or supplemen the proposed tests. A note of foreboding is, however, struck in the last paragraph of your leading article, which seems to me to advocate following the American system of making newborn testing for phenylketonuria a mandatory procedure. You cite Connecticut as having taken this step, whereas in fact the procedure has been enjoined by law on physicians and hospitals in at least 14 of the united States. ${ }^{1}$ It would have been well to state that much of the criticism of mass newborn screening which has developed in America-some of which your leading article alludes to-has stemmed from this legal enforcement. One hopes that authorities on this side of the Atlantic will be slow to follow suit and that the medical profession will give careful thought to the alternatives and likely sequelae before advocating this step.
Perhaps the experience gained in the Republic of Ireland may show that there is more to be gained by seeking rather than demanding the co-operation of hospitals, doctors, and nurses. For the past two years scheme set up by the Department of Health has been in operation by which the Guthrie test for phenylketonuria has been made available on all newborn infants. The scheme has been free of charge and without emolument to the individuals collecting specimens. The results of the first 16 months of testing are shortly to be published ${ }^{2}$ and will not be anticipated here except to point out that since testing began on 1 February 1966 a coverage amounting to $80 \%$ of the newborn population has been achieved to date. Tests are carried out in a small central laboratory in this hospital with a small staff, and local organization and co-ordination are in the hands of the county medical officers of health. The experience gained has prompted the hope that when the results of the initial period are disseminated they will encourage those concerned with the newborn to achieve a higher and possibly full coverage.-I am, etc.,

\section{Department of Pathology,}

Seamus F. Cahalane.

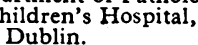

REFERENCES

State Laws Pertaining to Phenylketonuria, U.S. Department of Health, Education, and Welfare. 1965 Cahalane, S. F., Arch. Dis. Childh., in press.

\section{Lower Limb Injuries}

SIR,-Dehne and Immermann ${ }^{1}$ collected from the literature and from their own experience a total of 42 cases of fracture of the shaft of the femur combined with dislocation of the ipsilateral hip. In only 15 of these was the diagnosis of the hip dislocation made at the initial examination. In the majority of cases in which the dislocation was not discovered at the initial examination the diagnosis was not made until four to six months later.

Increasing attention has been paid in recent years to the importance of diagnosing proximal injuries in the region of the hip and pelvis in the presence of a more distal injury to one of the lower limbs. ${ }^{2}$ The patient may not make specific complaint of pain in the region of the injured hip. The surgeon directs his attention to the treatment of the distal injury-commonly fractures of the tibia and fibula-and the proximal injury is missed, often for weeks and sometimes for many months. The proximal injury may be a fracture or fractures of the pelvis, a fracture-dislocation of the hip joint, an intracapsular fracture of the neck of the femur, or a trochanteric fracture. The distal injury is usually fracture of the tibia and fibula, often compound, but it may be a foot or ankle injury, an injury to the knee such as compound fracture of the patella, or, as in Dehne and Immermann's series, a fracture of the shaft of the femur. Combined injuries of this sort are commonly seen in motorcyclists and pillion passengers. Failure to diagnose the proximal injury within a matter of hours or days of the accident often results in quite a marked avoidable disability in addition to any disability inherent in the diagnosed distal injury. The aggrieved patient may sue his surgeon for negligence and the 